\title{
Uma atualização da teoria política de Jean-Jacques Rousseau
}

\author{
A renewal of Jean-Jacques Rousseau's political theory
}

\author{
Inara Luisa Marin \\ inara.marin@gmail.com \\ (Centro Brasileiro de Análise e Planejamento, CEBRAP, São Paulo, Brasil)
}

\begin{abstract}
Resumo: As páginas seguintes têm em vista mudar o foco da discussão política em Rousseau colocando-o sob conceitos como piedade, autopreservação, intersubjetividade e reconhecimento ao invés de outros como liberdade, vontade geral, soberania, leis e razão. De um ponto de vista interno às obras, esta leitura deve servir para realocar este último grupo de conceitos numa perspectiva diferente; de um ponto de vista externo, o primeiro grupo de conceitos pode nos permitir inferir novas relações com as noções de negatividade, crítica e intersubjetividade. Este recorte visa mostrar como os paradoxos levantados por Rousseau ainda são centrais para as discussões sobre política e teoria em nossos dias.
\end{abstract}

Palavras-Chave: amor de si; amor-próprio; piedade natural; intersubjetividade; reconhecimento.

\begin{abstract}
The following pages aim to change the focus of the political discussion in Rousseau, setting it under concepts such as piety, self-preservation, intersubjectivity and recognition instead of others such as freedom, general will, sovereignity, laws and reason. From an internal point of view among Rousseau's works, this reading should be able to resituate this last group of concepts in a different perspective; from an external point of view, the first group of concepts could allow us to infer new relations with the notions of negativity, critique and intersubjectivity. This approach wants to demonstrate how the paradoxes taken by Rousseau are still central to the theoretical-political discussions of our days.
\end{abstract}

Keywords: self-love; love of self; natural pity; intersubjectivity; recognition.

DOI: http://dx.doi.org/10.11606/issn.2318-9800.v22i3p25-50

\section{Introdução}

Diversas personalidades cohabitaram em Jean-Jacques Rousseau: escritor, crítico, filósofo, copista, compositor, preceptor, legislador. Mas o que marca a singularidade de seus trabalhos são os inúmeros paradoxos que o atravessam. Tantos paradoxos poderiam sugerir uma obra esquizofrênica. Não é o caso. Entre sua obra e sua vida, a proximidade e a coerência dialogam todo o tempo na tentativa de pensar a cisão própria do homem vivendo em sociedade, já que nada mais pode garantir a unidade entre indíviduo e cidadão encontrada na antiguidade.

As páginas seguintes têm em vista, a partir de um recorte de textos bem restrito, mudar o foco da discussão política em Rousseau, colocando-a sob conceitos 
como piedade, autoconservação, intersubjetividade e reconhecimento, ao invés de outros como liberdade, vontade geral, soberania, leis e razão. De um ponto de vista interno às obras, esta leitura deve servir para realocar este último grupo de conceitos numa perspectiva diferente; de um ponto de vista externo, o primeiro grupo de conceitos pode nos permitir inferir novas relações com as noções de negatividade, crítica e intersubjetividade. Este recorte visa mostrar como os paradoxos levantados por Rousseau ainda são centrais para as discussões sobre política e teoria em nossos dias.

Uma vez que estamos tentando afirmar aqui a atualidade do pensamento político de Rousseau, tentaremos conectar a problemática deste autor com o debate entre Axel Honneth e Joel Whitebook. Em linhas gerais, este debate se dá a respeito da virada intersubjetiva operada por Jürgen Habermas e seguida por Axel Honneth; a questão feita por Whitebook é se esta virada intersubjetiva não ameaça a especificidade exata de uma teoria crítica, a saber, o aspecto negativo de sua crítica.

Dada a afirmação de Jean-Jacques Rousseau do Segundo Discurso, "o primeiro olhar que (o homem) lançou sobre si mesmo produziu-the o primeiro movimento de orgulho; assim, apenas distinguindo as categorias por considerar-se o primeiro por sua espécie, dispôs-se desde logo a considerar-se o primeiro como indivíduo" (Rousseau, 1988 , p.65), a pergunta que orienta este texto é a seguinte: Seria possível pensar em linhas bem gerais - tal afirmação de Rousseau como uma possível aproximação do conceito de reconhecimento proposto por Axel Honneth? (cf. Honneth, 2003). Se a resposta for afirmativa, e acreditamos que seja, que tipo de orientação teórica então poderíamos atribuir a este "insight" de Rousseau? Poderia ele ser entendido como uma outra vertente que não a de inspiração hegeliana proposta por Honneth? Seria Rousseau um representante de um negativismo ontológico social? Seriam essas duas opções irreconciláveis quando se trata da filosofia política de Jean-Jacques Rousseau?

Se partirmos das afirmações do Segundo Discurso, é claro que ficaremos tentados a dizer que uma teoria do reconhecimento em Rousseau só poderia ser negativa, já que certamente podemos responsabilizar a sociedade por todos os males que afligem os homens. 0 autor nos diz de próprio punho que vai apresentar a seus leitores "os vários acasos que puderam aperfeiçoar a razão humana, deteriorando a espécie, tornando mau um ser ao transformá-lo em ser social” (Rousseau, 1988). Mas se, por um lado, o texto de Rousseau nos autoriza a fazer tal diagnóstico, por outro, como entender, por exemplo, a seguinte afirmação de Rousseau no Manuscrito de Genebra (a primeira versão do Contrato Social): "só começamos propriamente a nos tornar homens depois de termos sido cidadãos” (Rousseau, 1964, p.287). Tal afirmação nos alerta que devemos proceder com prudência para não cairmos na tentação de começar a encontrar contradições no filósofo. Ao assumirmos esta posição cautelosa, 
não fazemos mais do que nos alinhar a uma tradição que já data de uma leitura da obra de Rousseau proposta por Ernest Cassirer em A Questão Jean-Jacques Rousseau (Cassirer, 1997), ${ }^{1}$ onde visava afastar a interpretação corrente de que o conjunto dos trabalhos de Rousseau era contraditório. Pode-se sim falar em paradoxo no caso de Rousseau. E justamente esses paradoxos, tão bem apontados por Rousseau, foram objeto de problematização de diversos autores em relação aos mais variados aspectos de sua obra. Temos, por exemplo, Jean Starobinski, que desde o título de seu livro - Jean-Jacques Rousseau: A transparência e o obstáculo - já põe à vista a relação paradoxal que queremos evidenciar; ou Bento Prado Jr., em seu estudo sobre - Ensaio sobre a Origem das Línguas, em que o par de oposição a ser explicado será linguagem-retórica ou comunicação-técnica; ou ainda, José Roberto Salinas com o par essência e aparência; e finalmente Milton Meira do Nascimento, na sua leitura do Contrato Social como escala e programa. Nesta mesma linha, ou seja, sem perder de vista os paradoxos da teoria rousseauista, vamos proceder a uma investigação em que os termos em pauta serão de um lado intersubjetividade - sociabilidade e, de outro, independência - estado de natureza.

O esquema da nossa apresentação será: I) vamos resumir inicialmente o que significa uma teoria do reconhecimento com base intersubjetiva como a honnethiana; II) para bem compreender o estatuto da intersubjetividade e da sociedade em Rousseau, vamos então proceder explicitando qual é a função do estado de natureza em Rousseau. Aqui vamos evocar alguns de seus adversários: de um lado Diderot e a sua vontade geral da espécie e, de outro, Hobbes com a guerra de todos contra todos. Desta apresentação, poderemos então concluir a radicalidade da formulação de Rousseau, que tem como principal característica a função de modelo deste estado de natureza, cujo estatuto é hipotético; III) prosseguiremos então com a apresentação dos dois móbeis de ação que Rousseau propõe para o homem no estado de natureza e qual a relação entre ambos, o que nos permitirá concluir que, para nosso autor, as relações socias não têm valor necessariamente negativo.

I.

Tendo em vista que a intenção principal deste artigo é interrogar o texto de Rousseau a partir da questão da intersubjetividade, vamos nos restringir por ora a apresentar os contornos da temática da intersubjetividade no livro de Axel

\footnotetext{
1 Paradoxo não quer dizer contradição, como tão bem já nos mostrou Ernest Cassirer que, em 1932, ao buscar inspiração na distinção de Diderot entre sistema e espírito sitemático, apresentava à Sociedade Francesa de Filosofia uma leitura que admitia a unidade do pensamento nos trabalhos de Rousseau. Seu texto estabeleceu novos marcos para o entendimento do conjunto da obra do pensador francês, que até então era vista como contraditória. Cassier nos propõe que pensemos a coesão das ideias de Rousseau, sem, no entanto exigir do autor um rigoroso sistema filosófico.
} 
Honneth Luta por reconhecimento. No final do texto, introduziremos a interlocução de Honneth com Joel Whitebook sobre o tema em questão.

Em Luta por reconhecimento, o conceito de intersubjetividade é central. Ele é justamente o medium capaz de resgatar o conteúdo normativo da integração entre a comunidade e o indivíduo. Vejamos como Honneth desenvolve o seu argumento no que concerne à filosofia hegeliana.

$\mathrm{Na}$ primeira parte de seu livro, Honneth nos mostra como a perspectiva do reconhecimento perpassa toda a obra de Hegel. Para Honneth, o que está em questão ao longo do texto hegeliano é evidenciar que o conflito serve de fundação para uma comunidade ética, ou seja, que o conflito tem função social. Trata-se, portanto, de apresentar o modo como a noção de intersubjetividade - cuja categoria central para a sua compreensão é a de conflito, luta - pode conduzir a uma comunidade ética. Esta intersubjetividade será o que Hegel vai relegar a um segundo plano no desenvolvimento posterior de sua obra, começando pela Fenomenologia do espírito². Honneth nos aponta que esta mudança de posição hegeliana se dá à medida que a base para a sua teoria política deixa de ser o esquema aristotélico e passa a ter como referência a teoria da consciência. ${ }^{3}$

$\mathrm{Na}$ segunda parte, trata-se de mostrar que, apesar da perspectiva mais empírica implicada na ideia de reconhecimento, seus pressupostos - ainda dotados de forte carga metafísica ${ }^{4}$ - não podem mais ser sustentados por uma filosofia cuja preocupação contemporânea é constituir uma teoria normativa da sociedade que seja crítica. ${ }^{5}$ Honneth tem então que lançar mão da interpretação empírica da psicologia social de George Mead para substituir os pressupostos especulativos hegelianos por outros que passem pelo teste da realidade empírica. ${ }^{6}$ Destituir os pressupostos especulativos de Hegel significa entender as premissas intersubjetivas

2 "Hegel pagou o ganho teórico de sua virada para a filosofia da consciência com a renúncia a um intersubjetivismo forte" (Honneth, 2003, p.66).

3 "Visto que Hegel abandona, junto com o aristotelismo de seus primeiros escritos da época de Jena, a ideia de uma intersubjetividade prévia da vida humana, ele agora não pode mais pensar o processo de individualização como um processo em que o indivíduo se desliga conflituosamente das relações comunicativas já existentes; sua teoria política da eticidade chega a perder de modo geral o caráter de uma 'história da sociedade' de uma análise da transformação gerida nas relações sociais, tomando aos poucos a forma de uma análise da formação do indivíduo para a sociedade" (Honneth, 2003, p.68).

4 "Mas sua reflexão permanece ligada à pressuposição da tradição metafísica, visto que não considera relação intersubjetiva como um curso empírico no interior do mundo social, mas a estiliza num processo de formação entre inteligências singulares" (Honneth, 2003, p.120).

5 "Uma abordagem que pretenda adotar o modelo de Hegel como estímulo para uma teoria social de teor normativo não pode se dar por satisfeita com esse fundamento meramente especulativo; daí ser preciso primeiramente uma reconstrução de sua tese inicial à luz de uma psicologia social empiricamente sustentada" (Honneth, 2003, p.121).

6 "Portanto, antes que se possa retomar hoje essa tipologia no sentido de uma reconstrução atualizadora, é necessária uma fenomenologia empiricamente controlada de formas de reconhecimento, mediante a qual a proposta de Hegel pode ser examinada e, se for o caso, corrigida" (Honneth, 2003, p.122). 
do modelo hegeliano do reconhecimento como formas de reconhecimento que vão se diferenciando na medida em que aumenta o nível de autonomia do agente. A sequência apresentada por Hegel tanto em System of Ethical Life quanto em Realphilosophie é a seguinte: o amor, a lei e a vida ética. É a partir disso que Honneth encaminha os passos de seu argumento na direção de construir uma gramática moral dos conflitos sociais. A resolução tem a virtude de submeter ao teste da empiria o desenvolvimento hegeliano, segundo o qual os estágios de reconhecimento se movem em uma determinada direção, a qual pode ser mapeada a partir das formas sociais de desrespeito (Honneth, 2003, p.122). Vale ainda acrescentar que é justamente a partir da categoria da intersubjetividade que Honneth vai reconstruir Hegel, e isso porque tal categoria permite que se forneça uma justificativa filosófica para o latente princípio normativo da teoria crítica, tradição à qual Honneth se filia. A teoria do reconhecimento proposta por Axel Honneth tem em vista, conservando a preocupação normativa da escola de Frankfurt, ampliar o foco da transformação crítica que, no seu entender, é ainda exclusivamente dominada pela produção material. ${ }^{7}$ Desta maneira, o "insight" emancipatório da crítica se localizaria em uma luta dentro dos domínios da experiência humana ordinária. Como ponto de partida para sua reflexão, Honneth recupera então o jovem Hegel e sua grande descoberta, isto é, a pressuposição de que só existe reconhecimento se essa operação tiver um outro que a reconheça, de modo que o desejo de reconhecimento só se realiza se o homem for inserido em um contexto social de reciprocidade. A radicalidade da formulação honnethiana está no fato dela afirmar que a intersubjetividade está lá desde sempre; faz-se necessário, portanto, que repensemos a dicotomia indivíduo-sociedade, pois o sujeito é desde sempre produto de relações socias. Desta maneira, está guardado o fundo hegeliano de esquerda de sua teoria que pretende ter uma visão crítica da sociedade, podendo assim se referir a uma instância prática, pré-teórica que existe no mundo cotidiano, diga-se a intersubjetividade. A partir desta, podemos chegar à instância normativa que dá as orientações de uma comunidade ideal, de uma sociedade não alienada, e que está desde sempre lá, pois é através da intersubjetividade que os indivíduos se constituem. Acreditamos ter ficado claro, nesta breve e incompleta exposição, a que nos referimos ao falar de uma vertente de inspiração hegeliana, ou intersubjetiva, para a teoria do reconhecimento como proposta por Honneth.

II.

Uma leitura bastante difundida na época em que o Discurso sobre os fundamentos e origem da desigualdade entre os homens foi publicado atribuía a seu autor um saudosismo em relação ao estado de natureza, que o teria conduzido a

7 Sobre este tema, ver Honneth, 1991. 
defender que a melhor coisa para a humanidade era um retorno a tal estado. Temse registro que Voltaire escreveu a Rousseau: “Dá vontade de andar de quatro patas quando se lê vossa obra. Como, todavia, perdi este hábito há mais de sessenta anos, sinto, infelizmente, que me é impossível retomá-lo, e deixo essa postura natural àqueles que dela são mais dignos do que vós, ou do que eu mesmo" (Voltaire, 1971, p.268). Atualmente, a discussão acerca do estatuto do estado de natureza na filosofia política de Jean-Jacques Rousseau já tem um ponto consensual: concorda-se que o estado de natureza tem caráter puramente hipotético.

Para nós, interessa examinar neste primeiro momento qual é o significado que a proposição hipotética do estado de natureza, que tem como principal característica a independência entre os homens, adquire no interior da doutrina política de Rousseau. Tentaremos evidenciar a importância da função de modelo ${ }^{8}$ do estado de natureza com estatuto de hipotético sob dois aspectos. Sob um primeiro aspecto, gostaríamos de apontar a função de parâmetro de julgamento que desempenha a noção de homem natural, com suas caraterísticas e potencialidades. Ao mesmo tempo, o que já se anuncia é que não se pode pretender qualquer legitimidade na instituição de sociedades instituídas pensadas a partir do homem natural, posto seu estado natural ser o de independência e suas faculdades estarem somente em potência. Como resultado desse padrão, temos então no texto de Rousseau uma crítica pesada e radical às sociedades instituídas de seu tempo. 0 segundo aspecto do modelo do estado de natureza está na radicalidade com que Rousseau afirma o seu caráter hipotético, evidenciando assim que não há passagem, mas sim ruptura entre o homem natural e o homem social. Com isso, Rousseau também desqualifica qualquer fundamento legítimo para as sociedades pensadas a partir da mera agregação dos indivíduos.

Na primeira parte do Discurso sobre a origem e o fundamento da desigualdade entre os homens, Rousseau formula a hipótese do estado de natureza como uma conjectura, extraída apenas da natureza das coisas. No caso do homem,

a religião nos ordena a crer que, tendo o próprio Deus tirado o homem do estado de natureza logo depois da criação, são eles desiguais porque assim o desejou; ela não nos proíbe, no entanto, de formar conjecturas extraídas unicamente da natureza do homem e dos seres que o circundam, acerca do que se teria transformado o gênero humano se fora abandonado a si mesmo (Rousseau, 1988, p.42, grifos meus).

Tal distinção é fundamental, pois permite ao autor marcar de saída sua posição com relação aos outros "filósofos que examinaram os fundamentos da sociedade (e) sentiram necessidade de voltar até o estado de natureza, mas nenhum deles chegou até lá" (Rousseau, 1988, p.39).

Rousseau dirige várias críticas a outras definições do estado de natureza, mas

8 Quando nos referimos a modelo, é sempre com o sentido de padrão ou parâmetro de julgamento. 
entende que todas elas têm algo em comum: o fato de seus examinadores terem considerado tal estado como realmente existente. ${ }^{9}$ Tal ausência de dúvida sobre a existência de fato do estado de natureza, e também a atribuição ao homem natural de qualidades que só haveriam de aparecer com o advento da sociedade (Rousseau, 1988, p.40), permitiu a esses espíritos postular uma passagem não problematizada entre a história hipotética e a história real, passagem que a caraterização rousseauista de um homem natural, que é pura potencialidade, ${ }^{10}$ não vai permitir.

De um lado, temos Thomas Hobbes que, para Rousseau, parece não ter tirado de sua crítica ao direito natural as consequências necessárias, pois atribui ao homem no estado de natureza paixões que ele só terá desenvolvido com o advento da sociedade. Tais paixões teriam como princípio de ação do homem unicamente a conservação de si, o que faria do homem natural um ser naturalmente mal, cujo resultado já conhecemos: a luta de todos contra todos. O que Hobbes não vê é que ainda existe um outro princípio, a piedade natural que equilibra a ação da conservação de si. ${ }^{11} \mathrm{Ou}$ seja, Hobbes acerta ao recusar a relação moral que Puffendorf postula para o estado de natureza, mas erra ao atribuir uma maldade natural ao homem, o que permite que se pense uma passagem não problemática do estado de natureza para o estado de sociedade, passagem na qual o Estado será visto como um Leviatã. A sociabilidade humana assim tem que necessariamente assumir um papel negativo. ${ }^{12}$

De outro lado temos Denis Diderot com seu verbete "Direito Natural" publicado na Enciclopédia, e a ideia ali veiculada de uma vontade geral da espécie. No dito verbete, Diderot coloca de início a pergunta pela definição do direito. 0 autor procede então afastando a questão do direito da esfera do particular, para afirmar em seguida que a única coisa que pode fundar o direito é a vontade geral da espécie.

9 "Não chegou mesmo a surgir, no espírito da maioria dos nossos, a dúvida quanto a ter existido o estado de natureza" (Rousseau, 1988, p.40).

10 "Depois de ter mostrado que a perfectibilidade, as virtudes sociais e outras faculdades que o homem natural recebera potencialmente jamais poderão desenvolver-se por si próprias, pois para isso necessitam do concurso fortuito de inúmeras causas estranhas, que nunca poderiam surgir e sem as quais ele teria permanecido eternamente em sua condição primitiva" (Rousseau, 1988, p.68).

11 Voltaremos a essa discussão mais à frente.

12 Uma outra possibilidade de leitura da luta de todos contra todos está justamente em Luta por Reconhecimento de Axel Honneth. A ideia que nos parece bastante interessante destacar é a de uma leitura da teoria da autoconservação com um cunho emancipatório. Honneth irá reabilitar para a sua construção de uma gramática moral ninguém menos que as duas "bestas" individualistas, Maquiavel e Hobbes, que desde sempre foram duramente criticados pelos ditos teóricos democratas da filosofia e ciência política, uma vez que sua leitura só poderia conduzir a um Estado onde a democracia, se exercitada, seria prerrogativa de poucos. O que está em jogo então nessa reabilitação de autores malditos para a tradição democrática? Seria por demais ingênuo, por um lado, acreditar que eles são ali apresentados apenas como o inimigo a ser combatido. Por outro lado, seria também ingenuidade acreditar que Honneth esqueceu sua herança. Acreditamos que tal escolha, longe de ser um descuido, tem um sentido muito mais profundo do que as poucas páginas a ela atribuídas em no livro de Honneth. Trata-se, antes de tudo, de tentar nuançar a verdade estabelecida de que pensar que o indivíduo e sua realização seja incompatível com uma teoria do Estado dita democrática. 
Essa vontade geral da espécie, por sua vez, é "a regra de conduta dos particulares de uma mesma sociedade, de um particular em relação à sociedade da qual é membro, e da sociedade em relação a outras sociedades" (Rousseau, 1988, p.62). Ou seja, o padrão de conduta é sempre o mesmo, é a mesma regra comum que vale para todos, seja ele um particular ou uma sociedade. Essa unidade é dada pela razão, que faz sempre o papel de mediadora: "A vontade geral é em cada indivíduo um ato puro do entendimento que raciocina no silêncio das paixões sobre aquilo que seu semelhante tem direito o de exigir" (idem, ibidem). Temos portanto que, para Diderot, o direito natural é fundado na vontade geral da espécie e que esta é atualizada pela razão, de modo que todo esse processo é apresentado como um desenvolvimento contínuo. Além disso, à passagem conceitual corresponde uma passagem real, o direito positivo surge do direito natural e está nele fundado. Mesmo que, na "ordem da razões", tenhamos que começar pelo direito positivo, o caminho deve nos revelar a "ordem das matérias", que mostra a prioridade do direito natural e da vontade geral.

O problema aqui para Rousseau está no pressuposto falso de que todos os problemas da sociedade possam ser resolvidos pela pura razão, e de que o motor da política é essa razão que dissolve todos os empecilhos a sua propagação. Se concebermos como natural e contínua a passagem do estado de independência ou estado de natureza para a sociedade, como faz Diderot, estaremos propondo verdadeiros absurdos. E o erro de Diderot está em que ele supõe - como, de resto, a tradição moderna - que possamos compreender a sociedade a partir da agregação dos indivíduos, com suas paixões, interesses e virtudes. A sociedade não pode ser constituída diretamente a partir do modelo do particular, entre um e outro não há continuidade. Ou seja, para Rousseau, o erro de conceber a passagem ao estado de sociedade como contínua e sem ruptura é análogo ao erro de conceber a sociedade como agregado de indivíduos. Como sabemos, essa concepção faz de Rousseau uma estrela única no céu da filosofia moderna. Por isso, se Diderot nos diz: "Sou homem e meus únicos direitos naturais inalienáveis são os da humanidade", Rousseau não tarda em retrucar: "só começamos propriamente a nos tornar homens depois de termos sido cidadãos" (Rousseau, 1964, p.287).

Temos claro, portanto, que a diferença em relação a seus interlocutores é que para Rousseau é "unicamente da ordem social estabelecida entre nós que tiramos as ideias daquilo que imaginamos" (Rousseau, 1964, p.287). Não podemos pressupor como fundantes estados originários cuja constatação depende do tempo presente, da "ordem social estabelecida entre nós". Tais estados podem e devem servir como hipóteses, como parâmetros de julgamento da ordem social dada. Mas colocar estados hipotéticos no lugar de fundamentos é renunciar à compreensão da sociedade moderna.

Para então bem compreendê-la e dela alcançar um bom diagnóstico, faz-se 
necessário colocar em dúvida a existência real do estado de natureza. Essa dúvida para Rousseau é fundamental, pois permite que nosso autor reconheça a necessidade de se esclarecer qual é o estatuto da noção de estado de natureza hipotético, mesmo não pretendendo com isso explicar ou justificar as estruturas de poder estabelecidas; mesmo não pretendendo formular uma teoria, no sentido tradicional da expressão, sobre a origem do estado ou sobre o direito natural. Enquanto seu estado de natureza tem caráter hipotético, ele pode ser entendido como parâmetro de julgamento, o que, por sua vez, dá a esta formulação um alto teor crítico:

não constitui empreendimento trivial separar o que há de original e de artificial na natureza atual do homem, e conhecer com exatidão um estado que não existe mais, que talvez nunca tenha existido, que provavelmente jamais existirá, e sobre o qual se tem, contudo, a necessidade de alcançar noções exatas para bem julgar de nosso estado presente (Rousseau, 1988, pp.32-3).

Tendo em vista esta difícil tarefa, Rousseau divide o texto do Segundo Discurso em duas partes. A primeira é o estado de natureza enquanto pura hipótese. Lá temos a apresentação do homem natural sob três pontos de vista: o físico, o metafísico e o moral. Na segunda parte do texto, temos a hipótese transformada em história pelo advento da propriedade, fator que atribui necessidade à contingência da primeira parte.

Vamos inicialmente seguir a Lettre au Monseigneur de Beaumont (Rousseau, 1969), ${ }^{13}$ já que lá nosso autor faz uma sintese muito clara do Segundo Discurso no qual apresenta o estado de natureza como tendo três fases. ${ }^{14} \mathrm{Na}$ primeira, os homens se assemelham aos animais: todas as suas características humanas encontram-se somente em potência nesse ser, todas as suas relações são imediatas. "Neste estado o homem só conhece a si mesmo, ele não vê seu bem estar oposto nem conforme ao de ninguém; ele não ama ou odeia nada; limitado somente ao seu instinto físico, ele é nulo, ele é um animal: e é isto que eu fiz ver no meu Discurso sobre a desigualdade" (idem, p.936). Na segunda etapa do estado de natureza, temos então a atualização das caraterísticas metafísicas e a transformação das morais,

quando, por um desenvolvimento do qual eu mostrei o progresso, os homens começam a jogar os olhos sobre os seus semelhantes, eles começam também a ver as suas relações e as relações entre coisas, a adotar ideias de conveniência, justiça e de ordem: o belo moral começa a se lhes tornar sensível, e a consciência age:

13 Tal carta é redigida por ocasião de uma resposta a objeções que the foram feitas pelo Monseigneur de Beaumont à publicação do Emílio.

14 Não se deve inferir que Rousseau tenha acrescentado uma fase que não se encontrava no texto do Segundo Discurso ao apresentá-lo como tendo três fases. Na economia interna do Segundo Discurso, o recurso a duas partes tem a intenção de marcar uma ruptura entre natureza e sociedade, enquanto que na Lettre trata-se de fazer uma síntese dos argumentos do texto marcando agora não a absoluta negatividade da passagem, mas sim seu aspecto "positivo", o que corresponde a uma defesa do texto do Emílio. Trata-se, portanto, de apontar que a emancipção já está dada junto com a negatividade. 
portanto eles têm virtudes; e se eles têm também vícios, é porque seus interesses se cruzam, e porque sua ambição se desperta à medida que suas luzes se ampliam. Mas enquanto houver menos oposição de interesses do que concurso de luzes, os homens são essencialmente bons. Veja o segundo estado (idem, p.937, grifo nosso).

Na terceira fase, o caráter hipotético do estado de natureza se enfraquece, pois, uma vez desencadeados os elementos que originam a desigualdade, a contingência se transforma em necessidade.

Quando enfim todos os interesses agitados se chocam, quando o amor de si posto em fermentação se torna amor próprio, que a opinião, tornando o universo inteiro necessário a cada homem, os torna todos inimigos natos uns dos outros, e fazendo com que um só encontre o seu bem no mal do outro, então a consciência, mais fraca do que as paixões exaltadas, é sufocada por elas, e não sobra senão na boca dos homens como uma palavra que faz os homens se enganarem mutuamente. Cada um finge sacrificar os seus interesses em nome do interesse público, e todos mentem. Só querem o bem público quando este acorda ao seu: também é esse acordo que é objeto do verdadeiro político que procura fazer os homens felizes e bons. Mas é agora que eu começo a falar uma língua estrangeira, tão pouco conhecida pelos leitores quanto pelo senhor. Veja, Monseigneur, o terceiro e último termo a partir do qual nada se pode fazer: e veja então como os homens sendo bons se tornam maus (Rousseau, 1969, p.937).

Apresentadas as três fases, vamos agora desdobrá-las. Para um exame mais detalhado vamos retornar, então, ao texto do Segundo Discurso. Deveremos encontrar neste o equivalente dessa sociabilidade cujo valor pode ser dito "positivo", não conflituoso. Essa análise é necessária para que bem possamos entender o estatuto da intersubjetividade no texto de Rousseau, nessa fase que o autor chama de sociedade nascente, propiciada pela atualização das características metafísicas: diga-se, a perfectibilidade e capacidade de ser agente livre, e a transformação das morais; diga-se a conservação de si em amor de si e este em amor próprio e a piedade natural em consciência ou virtude moral.

Antes de continuar, que me seja permitida uma observação. É importante deixar claro que, da perspectiva de leitura que adotamos, ou seja, ler o Segundo Discurso como um texto que faz a crítica “de nosso estado presente”, pode-se inferir que a formação social poderia ser completamente distinta daquela que Rousseau nos descreverá ao longo de toda a segunda parte do texto, ou seja, a história tal qual deve ter sido. Isto ocorre justamente porque a sociabilidade, por si só, não determina a maldade na sociedade.

Retomando a exposição de Rousseau no Discurso sobre o fundamento e a origem da desigualdade entre os homens, temos na sua primeira parte o homem natural sob três pontos de vista: o físico, o metafísico e o moral (Rousseau, 1988, p.46). Sobre o físico não vamos nos deter aqui, posto a sua única característica ser 
a independência, ou a ausência de relação entre os homens. ${ }^{15}$ Contudo talvez não seja demais ainda lembrar uma afirmação de Rousseau proferida a esta altura do texto e que causou tanto espanto junto a seus contemporâneos: "Se ela (natureza) nos destinou a sermos sãos, ouso quase assegurar que o estado de reflexão é um estado contrário à natureza e que o homem que medita é um animal depravado" (Rousseau, 1988, p.45). E “quase”, não porque não se possa concluir isso com certeza, mas sim porque existem no homem outras distinções que fazem com que ele seja essencialmente diferente do animal. Do ponto de vista físico, das suas necessidades animais, pode-se afirmar que a meditação deprava o animal, na medida em que o afasta da natureza, alimentando uma série de paixões que passarão a constituir uma "segunda natureza”, resultado de um processo de "desnaturação". Podemos então entender desnaturação como socialização? Sem qualquer dúvida que sim, mas a questão de que se trata agora é saber se essa sociabilidade é má (ou negativa). Dito de outro modo, trata-se agora de saber se para Rousseau o ser social é mau já de saída pelo simples fato de ser social, pelo fato de estar em relação com os outros.

0 que Rousseau mostra é que as relações intersubjetivas - sobre as quais as relações de reconhecimento são construídas - são relações conflitivas por excelência, mas dizer que elas são conflitivas não quer dizer necessariamente que elas determinam a maldade na sociedade, ou, nas palavras de Rousseau, que elas necessariamente autorizam a desigualdade política entre os homens. 0 que se afirma é que o conflito pode se desenvolver em qualquer direção, a saber, na direção da sociedade moral, que teria como base o equilíbrio entre razão instrumental (autoconservação ou amor de si) e virtude (piedade natural), e da sociedade instrumental, onde a razão instrumental (amor próprio) reinaria sem restrições. Isto porque a harmonia ou o perfeito equilíbrio só podem ser garantidos no estado de natureza, o que para Rousseau requer a ausência de relações entre homens. Assim, se fossemos responder à questão: "o self é social dos pés a cabeça?" [is the self social all the way down?], a resposta seria sim, se entendermos o social como conflitivo, pois esta segunda natureza do humano, a natureza social, é ela própria um conflito entre a apreciação que damos a nós mesmos e aquela que damos aos outros - em outras palavras, nossas pulsões narcísicas e sociais. Rousseau nos apresenta uma crítica radical na qual não é necessário afirmar uma negatividade logo de saída. O conflito é estrutural, mas o equilíbrio reina. Como veremos, esta solução de Rousseau permite que pensemos justamente a passagem homem-sociedade, mesmo que enquanto ruptura, de tal maneira que a formulação não perde nem em teor crítico nem fica a dever à negatividade.

15 Conforme páginas anteriores, nas quais mostramos que o estatuto hipotético do estado de natureza - cuja principal característica é justamente a independência, ou a ausência de relação entre os homens - tem função de modelo para Rousseau, a noção de estado de natureza cria um padrão para bem julgar os homens como se encontram atualmente. 
Mas se o homem, do ponto de vista físico, é apenas um animal como os outros animais, também do ponto de vista moral ${ }^{16}$ há semelhanças importantes. 0 aspecto diferenciador aparece sob o ponto de vista metafísico: "Se há uma distinção em relação ao animal é porque o homem é livre e perfectível" (Salinas Fortes, 1997, p.63). Do ponto de vista metafísico, nosso autor vai detectar na capacidade de ser agente livre (Rousseau, 1988, p.47) ${ }^{17}$ e na perfectibilidade (idem, ibidem) ${ }^{18}$ as principais características distintivas do homem. Isso significa dizer que o homem é o único animal capaz de escolher se segue ou não o curso e as leis da natureza. Donde se conclui que ele, e só ele, deve ser responsabilizado pelo resultado de suas escolhas. Mas que necessidade teria o homem de escolher, se vive sempre só, vagando pelos bosques? Nenhuma, responde-nos o autor, pois se a liberdade de escolha e a perfectibilidade estão dadas no estado de natureza, elas o estão somente em potência, já que a independência própria do mesmo estado não fornece ocasião para atualização de tais faculdades. ${ }^{19}$

Porém, uma vez que essas sejam atualizadas, temos o homem com a sua perfectibilidade se desenvolvendo de maneira a aperfeiçoar o homem enquanto indivíduo, o que se dá com o apoio do livre arbítrio e da articulação da consciência dessa liberdade orientada na direção da individuação por essa faculdade de aperfeicoar-se - que estamos aqui chamando de razão, a mesma cujo exercício, poucos paragrafos atrás, Rousseau quase ousava afirmar depravar o homem. Esse processo de aperfeiçoamento do indivíduo vai, portanto, se dar por meio da razão, cujo desenvolvimento está necessariamente ligado ao desenvolvimento da paixões e a ela subordinado.

16 Fica claro então porque Rousseau diz, por exemplo, que a piedade natural é uma virtude "tão natural que as próprias bestas às vezes dão dela alguns sinais perceptíveis. Sem falar da ternura das mães pelos filhinhos e dos perigos que enfrentam para garanti-los, comumente se observa a repugnância que têm os cavalos de pisar num ser vivo. Um animal não passa sem inquietação ao lado de um animal morto de sua espécie..." (Rousseau, 1988, p.57.) É de suma importância observar, entretanto, que as características morais do homem natural se alterarão substancialmente no segundo estágio do estado de natureza. Daí que "Amor de si e pitié são paixões naturais $e$ primitivas: eis aí uma 'evidência' indomesticável a não ser indiretamente - por exemplo, quando se observa sua presença até mesmo no tirano que se comove ao assistir a uma tragédia, com os sofrimentos do protagonista" (Salinas Fortes, 1997, p.59).

17 "Mas no poder de querer, ou antes, de escolher e no sentimento desse poder só se encontram atos puramente espirituais que de modo algum serão explicados pelas leis da mecânica".

18 "Sobre a diferença entre o homem e o animal, haveria uma outra qualidade muito específica que os distinguiria e a respeito da qual não pode haver contestação - é a faculdade de aperfeiçoar-se."

19 "Mas, sem recorrer aos testemunhos incertos da história, quem não verá que tudo parece afastar do homem selvagem a tentação e os meios de deixar de ser selvagem? Sua imaginação nada the descreve, o coração nada the pede. Suas módicas necessidades encontram-se com tanta facilidade ao alcance da mão e encontra-se tão longe do grau de conhecimento necessário para desejar alcançar outras maiores que não pode ter nem previdência, nem curiosidade." (Rousseau, 1988, p.48). E mais adiante: "Que progresso poderia conhecer o gênero humano esparso nas florestas entre os animais? $\mathrm{E}$ até que ponto poderiam aperfeiçoar-se e esclarecerem-se mutuamente homens que, não tendo domicílio fixo nem necessidade uns dos outros, se encontrariam talvez, somente duas vezes na vida, sem se conhecer e sem se falar?" (Rousseau, 1988, p.50) 
Apesar do que dizem os moralistas, o entendimento humano muito deve às paixões, que, segundo uma opnião geral, lhe devem também muito. É pela sua atividade que nossa razão se aperfeiçoa, só procuramos conhecer porque desejamos usufruir e é impossível conceber por que aquele, que não tem desejos ou temores, dar-seia a pena de raciocinar. As paixões, por sua vez, encontram sua origem em nossas necessidades e seu progresso em nossos conhecimentos, pois só se pode desejar ou temer as coisas segundo as ideias que delas se possa fazer ou pelo simples impulso da natureza (Roussseu, 1988, p.48).

Cabe aqui tecer algumas considerações acerca do papel da razão, como apresentada no Segundo Discurso por Rousseau. Ou seja, trata-se de abordá-la junto ao desenvolvimento histórico das sociedades. Ocasião exemplar nos parece ser a citação anterior, na qual o autor nos aponta os delineamentos do vocábulo "razão" no que concerne à descrição factual do seu processo de aperfeiçoamento. 0 que observamos, portanto, é que a razão serve de instrumento às paixões que, por sua vez, servem de impulso a essa mesma razão, apontando assim para o caráter dialético da natureza humana. Donde se pode concluir que essa operação efetuada pelos homens do uso de suas luzes serve somente ao uso particular, ao fim privado, e por isso the chamaremos doravante razão calculadora ou razão instrumental.

Temos aqui mais uma vez a possibilidade de ver a marca da especifidade de Rousseau junto aos philosophes, pois ao insistir que a razão é instrumento das paixões e que seu desenvolvimento está vinculado ao das mesmas é que a nãoproblematização do papel instrumental da razão permite aos contemporâneos de Rousseau, entre outras coisas, postular como natural a superação dessa razão instrumental pela Razão esclarecida. Isto o texto de Rousseau não vai permitir, já que sua crítica incide justamente sobre o apoio falso de que todos os problemas da sociedade podem ser resolvidos pela pura Razão, e de que o motor da política é essa Razão que dissolve todos os empecilhos a sua propagação. Isso permite uma passagem não problemática entre o nível do indivíduo, do particular, das paixões e o nível da Razão ou do universal.

Temos até aqui um diagnóstico bastante sombrio, principalmente se nossa intenção não é atribuir à sociabilidade em Rousseau um valor negativo. Contudo, como sempre em Rousseau, não se trata de precipitar às conclusões, pois toda essa descrição negativa vem acompanhada de mais um condicional: "Seria triste, para nós, vermo-nos forçados a convir que essa faculdade (perfectibilidade), distintiva e quase ilimitada, a fonte de todos os males do homem" (Rousseau, p.47, 1988). Vamos, portanto, ver quais as condições para que esse diagnóstico não necessariamente se cumpra. Para tal, faz-se necessário perguntar pela possibilidade de uma forma de sociabilidade que tivesse como resultado algo distinto da sociedade desigual contemporânea de Rousseau. Temos, então, que fechar a descrição do homem natural. Precisamos agora abordar o ponto de vista moral para bem compreendermos 
qual o sinal a ser atribuído à sociabilidade.

III.

Do ponto de vista moral, Rousseau vai nos apresentar os dois princípios da ação humana, princípios esses que são sentimentos responsáveis pela conservação da espécie. São eles os únicos móbeis da ação do homem no estado de natureza: a conservação de si e a piedade natural. ${ }^{20}$ A conservação de si é comum a todos os animais, é o instinto básico de sobrevivência que permite aos animais, dentre eles o homem, preencher todas as suas necessidades físicas e se proteger de toda sorte de perigos que se the apresentam. ${ }^{21}$ Por que algo do ponto de vista do físico reaparece como princípio moral? Acreditamos poder inferir que Rousseau já percebe o potencial emancipador presente na luta pela autoconservação, como Honneth fará com Hegel. Em ambos os casos, tanto na apropriação de Hegel de Honneth quanto no das elaborações de Rousseau, ${ }^{22}$ trata-se de manter uma interlocução com Hobbes.

Rousseau afirma que "a piedade representa um sentimento natural que, moderando em cada indivíduo a ação do amor de si mesmo, concorre para a conservação mútua da espécie" (Rousseau, 1988, p.58). E prossegue o texto: "Com efeito, o que são a generosidade, a clemência, a humanidade, senão a piedade aplicada aos fracos, aos culpados ou à espécie humana em geral?" (idem, ibidem). A piedade $^{23}$ aparece como moderadora, como elemento que vai colocar o meio-termo,

20 "Há, aliás, outro princípio que Hobbes não percebeu: é que, tendo sido possível ao homem, em certas circunstâncias, suavizar a ferocidade de seu amor próprio ou o desejo de conservação antes do nascimento desse amor, tempera, com repugnância em ver sofrer seu semelhante, o ardor que consagra ao seu bem-estar. (...) falo da piedade" (Rousseau,1988, pp.56-57). "Certo, pois a piedade representa um sentimento natural que moderando em cada indivíduo a ação do amor de si mesmo, concorre para a conservação mútua da espécie" (idem, p.58).

21 Acrescente-se que Goldschmidt (1974, p.321) nos ensina que só se pode falar em moral do ponto de vista de fato.

$22 \mathrm{Na}$ economia interna do texto do Segundo Discurso, a piedade natural é introduzida como uma resposta a Hobbes que, na opinião do autor, parece não ter tirado de sua crítica ao direito natural as consequências necessárias.

23 No texto do Segundo Discurso, Rousseau utiliza os vocábulos "piedade" e "piedade natural" sem marcar de maneira taxativa a distinção entre um e outro. É importante notar, entretanto, que Salinas Fortes, ao comentar a Carta ao Monseigneur de Beaumont, nos explicita a sutil, porém importante diferença entre os termos: é que a piedade natural se altera à medida que o homem progride: "por bondade, ele deixa de praticar o mal, na medida em que traz consigo o sentimento de piedade, esta repugnance à mal faire inata, que nos torna solidários de todo ser sensível, fazendo-nos sofrer diante do espetáculo de seu sofrimento e que desenvolvida - como nos diz a Carta à Beaumont - transforma-se na consciência ou no amor à ordem". E também no seguinte trecho: "Mesmo a consciência, segundo a Carta à Beaumont, só pode se manifestar no segundo estágio do estado de natureza, que corresponde ao estado de sociedade nascente do Discurso sobre a desigualdade" (Salinas Fortes, 1976, p.116). Ou seja, existe uma diferença entre o sentimento inato, imediato e a consciência. Para evitar mal entendidos, já que estamos no universo conceitual do Segundo Discurso, quando nos referirmos à piedade natural, será sempre no sentido do primeiro estágio do estado de natureza, no qual todas as características humanas são pura potência, e quando nos referirmos somente à piedade, devemos entender por esse termo o que Rousseau 
que vai permitir a passagem do natural para a boa sociabilidade e, por isso, delineia implicitamente os limites para a ação da razão humana.

O autor nos diz: "Sem nos afastarmos do senso comum, é oportuno suspender o julgamento que poderíamos fazer de uma tal situação e desconfiar de nossos preconceitos até que, de balança na mão, se tenha examinado se há mais virtudes do que vícios entre os homens civilizados" (Rousseau, 1988, p.55). O que garante ao homem, entretanto, o porte da balança? ${ }^{24}$ De onde se pode concluir que o homem julgará corretamente? Aqui está justamente a função da piedade, que confere apoio à razão: "Mandeville compreendeu muito bem que, com toda a sua moral, os homens jamais passariam de uns monstros se a natureza não lhes tivesse conferido a piedade para apoio da razão; não compreendeu, no entanto, decorrerem dessa qualidade todas as virtudes sociais" (Rousseau, 1988, p.57), e isto até mesmo no caso do homem de sociedades degradadas, já que ela é tão forte que "até os costumes mais depravados têm dificuldade em destruir" (idem, ibidem). Ou seja, a razão ${ }^{25}$ como apresentada até aqui no Segundo Discurso, enquanto operação do entendimento cujo desenvolvimento está diretamente vinculado ao desenvolvimento das paixões, só leva em conta o outro enquanto meio para se conseguir o maior bem-estar possível. Já a piedade leva em conta o outro enquanto fim, ${ }^{26}$ segundo acreditamos poder concluir do seguinte texto de Rousseau:

É a razão que engendra o amor-próprio e a reflexão o fortifica; faz o homem voltarse sobre si mesmo; separa-o de quanto o perturba e aflige. É a filosofia que isola; por sua causa, diz ele, em segredo, ao ver um homem sofrendo: "Perece, se queres; quanto a mim estou seguro." Nada, além dos perigos da sociedade inteira, atrapalha o sono tranquilo do filósofo e o arranca do leito. Podem impunemente degolar um seu semelhante sob sua janela, ele só terá de levar as mãos às orelhas e ponderar um pouco consigo mesmo para impedir que a natureza, que nele se revolta, de identificarse com aquele que se assassina. 0 homem selvagem de modo algum possui esse talento admirável e, por falta de sabedoria e de razão, vemo-lo cada dia entregar-se temerariamente ao primeiro sentimento de humanidade (Rousseau, 1988, p.58).

A piedade representa a porta aberta para a possibilidade de se transformar a história humana, possibilidade esta contida na própria natureza humana. 0 trabalho

chama de consciência: ou a piedade já desenvolvida presente no segundo estágio do estado de natureza, ou a idade de ouro.

24 “ $N a$ busca das relações adequadas, tarefa da 'razão', é necessário que nos deixemos guiar pelo 'sentimento' e que conservemos, no seio mesmo da atividade a que já não podemos nos furtar, a nostalgia da passividade primitiva" (Salinas Fortes, 1997, p.78).

25 "O exercício do juízo vem junto à expressão dos sentimentos e evolui, por conseguinte, em função das imposições das paixões. A dialética do entendimento e a lógica da expressão estão imbricadas com o funcionamento das paixões no horizonte das relações sociais" (Salinas Fortes, 1976, p.51).

26 "Essa capacidade (da pitié) de identificação é a condição indispensável para que se constitua um vínculo efetivo, para além daquele formado com base no mero interesse: para que o homem deixe de girar apenas em torno de si, é necessário que ele tenha, nele mesmo, a capacidade de 'sair de si' e sentir como se fora outro" (Salinas Fortes, 1976, p.62). 
será então o de se reintroduzir essa virtude natural como o elemento de passagem para as outras virtudes, que deverão ser construídas. ${ }^{27} \mathrm{~A}$ piedade faz com que 0 homem se identifique ${ }^{28} \mathrm{com}$ o seu semelhante na fraqueza e na dor, é um sentimento de repugnância natural em ver sofrer seu semelhante, não obstante ela se dirija sempre a um particular, normalmente mais fraco, e dessa maneira regule as relações entre os homens. ${ }^{29}$ Dessa forma, a piedade contribui também e principalmente para a própria conservação mútua da espécie, o que significa dizer que um sentimento dirigido a um particular tem um fim que não se esgota em si mesmo, mas que o ultrapassa e propaga o bem do conjunto. Daí que Rousseau nos diga que a máxima inspirada na piedade ("Alcança teu bem com o menor mal possível para outrem”) é bem menos perfeita, mas talvez mais útil do que a máxima raciocinada ("faz a outrem o que desejas que façam a ti”). E prossegue: “numa palavra, antes nesse sentimento natural do que nos argumentos sutis deve procurar-se a causa da repugnância que todo homem experimenta por agir mal, mesmo independentemente das máximas da educação" (Rousseau, 1988, p.58). Nesse sentido, só se pode falar em "saudosismo" ou "nostalgia” de Rousseau com relação ao estado de natureza - ou mesmo em uma suposta "volta" a tal estado - como uma tentativa de ouvir a voz que vem de dentro, o chamamento desse primeiro sentimento de humanidade (idem, p.57) e não como recriação das condições concretas de vida do estado de independência. A piedade, "no estado de natureza, ocupa o lugar das leis, dos costumes e da virtude, com a vantagem de ninguém sentir-se tentado a desobedecer a tal doce voz" (idem, p.58). Desse modo, a piedade - essa virtude natural transformada pela ação de uma razão pública encarnada na figura do legislador - constituirá condição indispensável para se entender como Rousseau pensa e propõe intervenções na sociedade. Infelizmente, nosso recorte não permite que tratemos dessa questão neste artigo.

A piedade fornece o parâmetro (enquanto orienta uma forma de sociabilidade que leva em conta o semelhante enquanto fim e não enquanto meio) para que o

27 "A pitié é a matriz última de toda sociabilidade: moderando em cada indivíduo a 'atividade' do amor de si mesmo ela 'concorre à conservação mútua da espécie'. Eis, por conseguinte, a base sobre a qual se assentará todo relacionamento humano 'positivo'” (Salinas Fortes, 1976, p.62).

28 "A comiseração não passa de um sentimento que nos coloca no lugar daquele que sofre, sentimento obscuro e vivo no homem selvagem, desenvolvido mas fraco no homem civil, que importará tal ideia para a verdade do que digo senão, para dar-lhe mais força? A comiseração, com efeito, mostrar-se-á tanto mais enérgica quanto mais intimamente se identificar o animal espectador com o animal sofredor. Ora, é evidente que essa identificação deveu ser infinitamente mais íntima no estado de natureza do que no estado de raciocínio" (Rousseau, 1988, p.58, grifo meu).

29 Vejamos o que nos diz Salinas a respeito da identificação se dar com um ser que sofre: "A pitié é identificação sem supressão da separação, transporte 'imaginário' para fora e permanência real do 'espectador' junto a si; além disso, ela só se põe em ação, ao menos nos seus primórdios, nas suas manifestações mais elementares como identificação com o Outro sofrente. (...) 0 espetáculo do sucesso desperta, de preferência, a inveja ou o ressentimento. Regozijar-se com tal espetáculo seria próprio do sábio e reclamaria, por conseguinte, uma sofisticação da sentimento de pitié primitivo" (Salinas Fortes, 1976, p.60). O lugar deste sábio, que pode se alegrar com a felicidade do outro, é ocupado pela alma do legislador. No entanto, não vamos tratar disso neste artigo. 
homem possa agir bem mesmo em sociedade sem perder a sua humanidade - desde que suas leis sejam inspiradas nesses sentimentos, formando assim o espírito social de que Rousseau nos fala no Contrato Social. No que concerne às leis, elas deverão promulgar o amor à pátria, que nada mais é do que o amor de si ligado ao todo e não mais ao indivíduo. Deve ser procurado aí, na combinação de piedade e amor de si, acreditamos, o padrão que garante a construção de uma boa ação e possibilita uma sociedade mais justa, pois a piedade é uma qualidade da qual decorrem "todas as outras virtudes sociais" (Rousseau, 1988, p.57). Se nos recordarmos do que é virtude para Rousseau segundo o Discurso sobre a Economia Política: "e como a virtude nada mais é do que essa conformidade da vontade particular à geral" (Rousseau, 1995, p.32), acreditamos poder afirmar que a virtude será o nome sob o qual aparecerá em sociedade esse sentimento, já que no estado de natureza ela "concorre para a conservação mútua da espécie” (Rousseau, 1988, p.58). No estado de sociedade, onde todas as construções precisam de mediação, essa conformidade deverá ser construída e garantida pela virtude e pelas leis.

Antes de concluirmos a exposição da primeira parte do Segundo Discurso, é importante ressaltar o sentido e a importância da articulação de dois momentos, quais sejam, de um lado os dois móbeis da ação humana (a conservação de si e a piedade natural) e, de outro, o processo de individuação e socialização. A articulação entre esses dois pontos se dá para nós na medida em que o processo de individuação que leva ao estado societário está ancorado num desenvolvimento (como algo que estava envolvido, amalgamado) desmesurado, desproporcional da conservação de si frente à piedade e à ligação dessa dilatação com o desenvolvimento da razão enquanto puro instrumento desse móbil. A ênfase dada à piedade, por sua vez, será uma referência importante para o Contrato Social, se o entendermos como um constructo ideal no qual haveria lugar para um equilíbrio entre a conservação de si e a piedade natural transformados e reunidos pela razão (aqui não mais meramente enquanto razão instrumental da conservação de si, mas sim como a figura privilegiada do Legislador rousseauista) em amor à pátria e virtude, ambos sempre garantidos, e, principalmente, fomentados pelas leis. ${ }^{30}$

Concluamos então a primeira parte do texto de Rousseau. 0 que se percebe até aqui no texto de nosso autor é que, ao mesmo tempo em que sua argumentação parece simplesmente negativa (cf. Goldschmidt, 1974, p.382), destituindo o homem de qualquer sociabilidade natural, ele constrói paralela e implicitamente os parâmetros para o julgamento e a ação transformadoras em sociedade. Daí que, na segunda parte do texto, Rousseau nos apresente a contrapartida necessária (necessária

30 É neste sentido que entendemos o início do capítulo sobre as leis no Contrato Social: "Pelo pacto social demos existência e vida ao corpo político. Trata-se, agora, de the dar pela legislação, movimento e vontade, porque o ato primitivo, pelo qual esse corpo se forma e se une, nada determina daquilo que deverá fazer para conservar-se" (Rousseau, 1988, p.53). 
porque histórica) do rompimento do estado de natureza. É assim que, de certo modo, podemos considerar a conclusão da primeira parte como uma contraprova do movimento descrito até aqui. Nesse ponto do texto, Rousseau reflete sobre a história conjectural, de certa forma explicitando o papel que o estado de natureza hipotético desempenha enquanto critério para julgar a história humana. Escreve Rousseau:

Confesso que os acontecimentos que tenho de descrever podendo sobrevir de inúmeros modos, só por conjeturas posso decidir-me na escolha. Mas, além dessas conjeturas se tornarem verdadeiras razões quando são as mais prováveis que se possam extrair da natureza das coisas e os únicos meios que se possa ter para descobrir a verdade, as consequências que eu quero deduzir das minhas conjeturas, por isso não serão conjeturais, porquanto, sobre os princípios que acabo de assentar não se poderia estabelecer qualquer outro sistema que me fornecesse os mesmos resultados e do qual pudesse inferir as mesmas conclusões (Rousseau, 1988, p.63).

Até aqui, ${ }^{31}$ o que o autor nos apresenta é o estado de natureza do ponto de vista estritamente ideal, são puras conjecturas que, no entanto, têm por finalidade estabelecer um critério que permite saber o quanto o homem se desnaturou. $\mathrm{Na}$ segunda parte, ele tem como ponto de partida a mesma desigualdade que, por contraste, permitiu a ele construir o critério para julgar apresentado na primeira parte. No entanto, trata-se aqui de "mostrar sua origem e seus progressos nos desenvolvimentos sucessivos do espírito humano" (Rousseau, 1988, p.62). Ou seja, trata-se de apresentar sua história, apresentar o desenvolvimento cada vez mais exacerbado do amor-próprio em detrimento da piedade. Aqui a intersubjetividade já está contaminada pelos vícios e só pode desembocar numa desigualdade de relações que vai se perpetuar sob a forma de uma sociabilidade negativa.

Sob esse ponto de vista, então, fica explicado porque Rousseau nos diz que essas conjecturas se tornam verdadeiras razões: dada a desigualdade, temos um único encadeamento de fatos históricos que é o mais provável para explicar o curso que levou a ela. E essa é a única maneira de proceder para se aproximar da verdade. Se retornarmos agora ao nosso ponto de partida, diga-se, as três fases do estado de natureza, conforme apresentados na Lettre au Monseigneur de Beaumont, podemos então constatar que o caráter hipotético vai perdendo força ao longo das três etapas. ${ }^{32}$ Rousseau nos dirá, como discutido ainda acima, que as suas conjecturas se

31 Victor Goldschmidt caracteriza essa parte do texto como Le programme de la Seconde Partie et sa Méthode, na qual Rousseau vai fazer considerações metodológicas acerca da maneira como construiu seu texto (Goldschmidt, 1974, p.382ss.).

32 O conjunto do Segundo Discurso nos apresenta a hipótese de Rousseau sobre a origem e os fundamentos da desigualdade entre os homens. Esta hipótese, no entanto, não tem a mesma força ao longo de todo o texto. Pois, para formulá-la, nosso autor precisa construir em primeiro lugar um modelo de homem natural, construção que não pode apresentar qualquer característica do homem civil, já que sua função é medir o grau de desigualdade das sociedades. Ou seja, tal construção só poderá servir como modelo enquanto ela for apresentada como hipótese. Daí então dizermos que o caráter hipotético perde força ao longo do texto, pois na segunda parte do texto já não temos mais um modelo puramente hipotético, mas sim acontecimentos fortuitos que propiciam 
tornam verdadeiras razões, já que a ordem que apresenta para o desenvolvimento da desigualdade não é mais puramente contingente e sim necessária. ${ }^{33}$

Ou seja, não existe passagem necessária entre o estado de natureza e o estado de sociedade. Mas, dadas determinadas condições históricas, feitas de acasos e circunstâncias, somos conduzidos necessariamente ao estado de sociedade. Isto significa, de um lado, que o estado de sociedade não está inscrito no estado de natureza. Mas, de outro lado, temos alguns elementos no estado de natureza que são atualizados e amplificados pelas circunstâncias históricas que conduziram ao estado de sociedade. Deste modo, do ponto de vista analítico, é necessário separar esses dois momentos na exposição do texto, pois não se pode deduzir pura e simplesmente um do outro, já que isso poderia ser entendido como a justificação natural da desigualdade civil - e esse descuido nosso autor não pode se permitir, posto essa ser sua maior crítica a seus contemporâneos. É justamente aqui que cabe a apresentação da sociedade nascente como a época mais feliz e mais duradoura da história do homem. Ou seja, as primeiras relações entre os homens fazem com que a piedade natural desenvolva-se em consciência e conduza o homem natural a amar a ordem. Vejamos, mais uma vez o texto da Lettre:

O homem não é um ser simples; ele é composto de duas substâncias. Se todos os homens não estão de acordo sobre isso, nós o estamos, eu e o senhor, e eu tenho a tarefa de o provar aos outros. Isso provado, o amor de si não é uma paixão simples; mas esta tem dois princípios, a saber, o ser inteligente e o ser sensitivo, cujo bemestar não é o mesmo. 0 apetite dos sentidos tende para aquele do corpo, e o amor à ordem para aquele da alma. Este último, uma vez, desenvolvido e feito ativo, traz o nome de consciência, mas a consciência só desenvolve e age com as luzes do homem. É só através dessas luzes que ele vem a conhecer a ordem, e somente quando ele a conhece, sua consciência o leva a amá-la. A consciência é, portanto, nula no homem que nada compara e que não viu absolutamente suas relações (Rousseau, 1969, p.937).

Trata-se aqui de uma época feliz e duradoura da história do homem. Temos a possibilidade de falar na intersubjetividade, nos termos de Rousseau, nas relações entre os homens e nos seus progressos, como a idade do ouro. Temos, portanto a época do equilíbrio entre as virtudes e os vícios. A segunda vertente, ou o desequilíbrio, aparece com o advento da propriedade. "O verdadeiro fundador da sociedade civil

o desenvolvimento da desigualdade integrados à argumentação. A ligação entre os fatos, a sua causalidade, é ainda elaboração de Rousseau desempenhando então a tarefa que ele mesmo atribui ao filósofo, a saber, a de ligar os fatos. A partir do momento em que já temos indivíduos, interesses particulares, paixões, razão instrumental, propriedade, agricultura, metalurgia, não se trata mais de uma pura hipótese, mas já de uma descrição de "fatos considerados como bastante reais para ligar uma sequiência de fatos intermediários, desconhecidos ou considerados como tais, cabe a história quando existe apresentar os fatos que os ligam e porque, faltando a história, à filosofia cabe determinar fatos semelhantes que poderiam ligá-los" (Rousseau, 1988, p.63). Ora esses fatos semelhantes são os mais prováveis, de modo que o caráter hipotético inicial se enfraquece.

330 que entendemos por necessidade é a possibilidade de "discriminar etapas na produção dos males, [de modo que] é possível acompanhar seu 'progresso'” (Salinas Fortes, 1997, p.38). 
foi o primeiro que, tendo cercado um terreno, lembrou-se de dizer isto é meu e encontrou pessoas suficientemente simples para acreditá-lo” (Rousseau, 1988, p.65), transformando assim um fato (possessório) em direito (de propriedade).

Permitiremos-nos mais um desvio agora no que concerne à questão da propriedade. É com a citação anterior que se inicia a segunda parte do Segundo Discurso. ${ }^{34}$ Enquanto na primeira parte, acerca do estado de natureza, Rousseau parece seguir Hobbes (até o momento em que o acusa de não ter tirado as consequências do estado de natureza que ele, melhor do que os outros escritores políticos, havia tão bem formulado), na segunda parte do texto, nosso autor parece seguir Locke no que concerne à questão da propriedade. Até o advento da propriedade, ${ }^{35}$ não havia uma oposição necessária entre o desenvolvimento da razão e o declínio da natureza: "compelido [o homem natural] tanto pelo instinto quanto pela razão a defender-se do mal que o ameaça, é impedido pela piedade natural de fazer mal a alguém sem ser a isso levado por alguma coisa ou mesmo depois de atingido por algum mal" (Rousseau, 1988, p.68). O que introduz essa oposição como necessária é justamente a afronta, como bem lembrou o sábio Locke: "não haveria afronta se não houvesse propriedade" (idem, ibidem).

Isso significa dizer que, até então, a razão fomentada pelas paixões não ia além de responder aos chamamentos do amor de si. Esta operação da razão tinha como resultado colocar à disposição do amor de si ideias ou noções que não passavam de atributos "psicológicos". Ou seja, as operações da razão respondiam a sentimentos e diziam respeito ao conflito interno de um único homem. ${ }^{36}$ Mas, quando um homem

34 Ela é bastante significativa sob vários aspectos. Vamos primeiro considerar porque ela está aí colocada. Rousseau nos diz que foram necessários vários outros progressos para se chegar até esse estágio, mas ele não nos apresenta esses progressos em primeiro lugar. Sendo assim a introdução direta da questão da propriedade vem mais uma vez reforçar que não há passagem natural do estado de natureza para a sociedade civil e, dessa forma, reforçar também a ilegitimidade da sociedade desigual em que vivemos. Já do ponto de vista histórico, o início das agregações fica por conta do advento do indivíduo, orientando a história humana para a desigualdade com o advento da propriedade, que só depois de muito exercício das paixões consegue criar o hábito e desse hábito necessidades que por fim vencerão o homem e o farão dependente de seu semelhante: "Enquanto só [os homens no estado de natureza histórico] se dedicaram às obras que um único homem podia criar e às artes que não solicitavam o concurso de várias mãos, viveram tão livres, sadios, bons e felizes quanto o poderiam ser por sua natureza, e continuaram a gozar entre si das doçuras de um comércio independente; mas, desde o instante em que um homem sentiu necessidade de socorro de outro, desde que se percebeu ser útil a um só contar com provisões para dois, desapareceu a igualdade, introduziu-se a propriedade, o trabalho tornou-se necessário e as vastas florestas transformaram-se em campos aprazíveis que se impôs regrar com suor dos homens e nos quais logo se viu a escravidão e a miséria germinarem e crescerem com colheitas" (Rousseau, 1988, p.69).

35 Até falarmos em se instituir o direito de propriedade, utilizaremos os vocábulos posse e propriedade como sinônimos.

36 Tendo inicialmente se percebido enquanto o "primeiro indivíduo" da espécie, logo percebe outros seres que se comportam de maneira semelhante à sua. Visando então sua conservação, pressente que necessita estabelecer relações para com esses. Este processo se dá "por meio de um pressentimento tão seguro e mais rápido que a dialética, para seu proveito e segurança, achou melhor manter para com eles" (Rousseau, 1988, p.65). Surgem então os compromisso mútuos, só 
diz "isto é meu" e outro tenta se apossar desse mesmo objeto, o objeto externo real passa a ser um elemento a mais a ser equacionado pela razão na chave da satisfação, aí não mais do amor de si, mas do amor próprio. ${ }^{37} \mathrm{O}$ que se observa então é que tanto homens como objetos passam a ser considerados pela razão como meios para alcançar outros fins, outras satisfações. Deste modo, o homem não se portaria mais como o selvagem Caraíba descrito por Rousseau no início de seu texto, ${ }^{38}$ pois já se estabeleceram em seu espírito relações de necessidade e constância em lugar da prudência maquinal. ${ }^{39}$

Acreditamos a partir do recorte de texto que nos propusemos a tratar que não faz sentido pensar a intersubjetividade como um valor negativo, pois nem todas as sociedades se desenvolvem da mesma maneira, e nem a desigualdade moral entre os homens está fundada na sociabilidade: ela é resultado de uma determinada forma de sociabilidade que acabou por instituir a desigualdade moral enquanto valor. Vejamos que forma é essa: "primeiro olhar que [o homem] lançou sobre si mesmo produziulhe o primeiro movimento de orgulho; assim, apenas distinguindo as categorias por considerar-se o primeiro por sua espécie, dispôs-se desde logo a considerar-se o primeiro como indivíduo" (Rousseau, 1988, p.65). ${ }^{40} 0$ orgulho, essa primeira paixão, será o motor desse processo de sociabilização que será levado a cabo por uma razão orientada sempre na direção de alimentar esse mesmo orgulho individual, que se desenvolverá depois desse primeiro movimento, ou primeiro olhar, em um segundo movimento, ou segundo olhar: "cada um começou a olhar os outros e a desejar ser ele próprio olhado" (idem, p.67). Temos aqui por um lado o fato de esse processo se apresentar como não tendo ponto final: ele se desenvolve sucessivamente até dar seu primeiro passo na direção da desigualdade e do vício, quando “dessas primeiras preferências nasceram, de um lado, a vaidade e o desprezo, e, de outro, a vergonha e a inveja" (idem, ibidem). Mas esse é o primeiro de todos os passos? O que ocorreu antes foi, segundo Rousseau, a época mais feliz e a mais duradoura da história do homem. 0 olhar permite o momento em que algo se transforma; essa transformação aponta, no caso de Rousseau, não só para o vício social mas também para vertentes de sociabilidade que não foram levadas adiante, e nos mostra os potenciais que

observados enquanto se desfrutam suas vantagens e propiciam o bem-estar dos que por ele se comprometeram. Nestes compromissos não se verificam ainda as relações de constância.

37 "O amor de si, paixão indiferente em si mesma ao bem e ao mal, já sofreu alguma alteração, mas não se converteu ainda em amor-próprio. A transformação só se dará num terceiro estágio, depois da invenção da agricultura e da metalurgia, da divisão do trabalho que se segue e do estabelecimento da propriedade privada" (Salinas Fortes, 1976, p.116).

38 "De manhã vende o colchão de algodão e de tarde chora, querendo readquiri-lo, por não ter previsto que a noite seguinte necessitaria dele" (Rousseau, 1988, p.49).

39 "Acabaram por produzir-lhe uma certa espécie de reflexão, ou melhor uma prudência maquinal, que the indicava as precauções necessárias à sua segurança” (Rousseau, 1988, p.64).

40 Aqui aparece o indivíduo entendido enquanto parte que se considera um todo. 
ficaram encobertos, qual seria uma outra opção para esse mesmo olhar? Rousseau nos diz explicitamente na Lettre:

Quando, por um desenvolvimento do qual eu mostrei o progresso, os homens começam a jogar os olhos sobre os seus semelhantes, eles começam também a ver as suas relações e as relações entre coisas, a adotar ideias de conveniência, justiça e de ordem: o belo moral começa a se lhes tornar sensível, e a consciência age: portanto eles têm virtudes; e se eles têm também vícios, é porque seus interesses se cruzam, e porque sua ambição se desperta à medida que suas luzes se ampliam. Mas enquanto houver menos oposição de interesses do que concurso de luzes, os homens são essencialmente bons. Veja o segundo estado (Rousseau, 1969, p.937).

Ou, ainda, sobre as outras opções, leia-se no texto do Segundo Discurso, quando Rousseau nos apresenta essa fase como a idade do ouro. Nesta época os homens podiam se associar por alguma coisa, mas tão logo alcançado o objetivo, a associação se desfazia (Rousseau, 1988, p.65). O mal social ainda não é o fator determinante no curso da história: o homem já percebe que o concurso de suas forças traz comodidades (idem, p.66), que o amor conjugal e o amor paterno criam vínculos antes não existentes (idem, p.66). As primeiras preferências fomentam o exercício da razão, prova disso é o nascimento da ideia de consideração (idem, p.67). A piedade já sofre alteração (idem, p.68), pois a razão calculadora já começa a se exercitar. Mas tudo isso ainda é circunstancial, não tem força suficiente para orientar o curso da história. Daí que Rousseau escreva: "esse período de desenvolvimento das faculdades humanas, ocupando uma posição média exata entre a indolência do estado primitivo e a atividade petulante de nosso amor-próprio, deve ter sido a época mais feliz e mais duradoura" (idem, ibidem).

Portanto, no que concerne à história ${ }^{41}$ dos homens, se considerarmos seu início com o surgimento do processo de sociabilização, é possível sustentar, como Rousseau o faz, que no começo da história dos homens as relações entre estes não determinavam o mal social. Isto se dará apenas quando os vícios se tornarem mais fortes do que a virtude. A apresentação da articulação do processo de sociabilidade, ancorado num desenvolvimento desproporcional da conservação de si e vinculado ao desenvolvimento da razão enquanto puro instrumento desse móbil, exige que se tenha sempre em mente que o surgimento da sociedade por si só não determina a desigualdade entre os homens, a desnaturação, ou, se se preferir, a maldade na história, a sociedade enquanto o mal do homem; mas o processo de sociabilidade marca sim uma ruptura, uma quebra sem volta da unidade originária, que jamais poderá ser recuperada.

41 Entendemos que a citação que segue ajuda esclarecer o que entendemos por história: "Com o processo de socialização, as paixões intensificadas, detonando a perfectibilidade, conduzirão a novas 'luzes', as quais, por sua vez, retroagem sobre as paixões atribuindo-lhes novas qualificações e novas direções, que, novamente darão impulso ao aperfeiçoamento das faculdades intelectuais. Inaugura-se o ciclo evolutivo ou o circuito “histórico'” (Salinas Fortes, 1997, p.63). 
Me permitam, antes de dar por terminado este artigo, duas notas sobre a possibilidades de leitura que acompanhem a linha que vimos propondo até então. $\mathrm{Na}$ primeira, a sociabilidade não se apresenta enquanto valor absoluto, mas na relatividade dos hábitos e costumes que constituem um povo. E são justamente esses hábitos e costumes que vão na sociedade ocupar o lugar da piedade. Nessa linha, podemos entender como a função do olhar é mais uma vez fundamental, agora no texto das Considerações sobre o Governo da Polônia (Rousseau, 1982). Neste texto trata-se de ligar o olhar a um outro objeto que não o próprio indivíduo; a sua função é a mesma, mas seu objeto deve ser outro. Trata-se da maneira de interessar as paixões dos homens através do reconhecimento que se obtem a partir do olhar dos outros; tem-se então que redirecionar o olhar no sentido de uma imagem pública. Oportunidade exemplar nos parece ser o capítulo “Aplicação”. Ali Rousseau nos mostra como interessar os corações humanos. No momento constitutivo da individualidade, temos o olhar. Lembremo-nos do instante em que no Segundo Discurso surge a noção de indivíduo: “Assim o primeiro olhar que lançou sobre si mesmo produziu-the o primeiro movimento de orgulho; assim apenas distinguindo as categorias por considerar-se o primeiro por sua espécie, dispôs-se desde logo a considerar-se o primeiro indivíduo" (Rousseau, 1988, p.65). É claro que Rousseau não descreve esse momento como sendo de um único indivíduo, mas um momento pelo qual a história dos desenvolvimentos sucessivos do homem passou, o momento em que se constitui a identidade do homem enquanto indivíduo. É possível fazer dessa experiência uma experiência geral, um sentimento partilhado por um grupo, para que se possa construir uma identidade nacional, ou seja, fazer o homem se identificar com a imagem de cidadão? De maneira geral, os conselhos de Rousseau são muitos, mas eles sempre variam sobre o mesmo tema, ou seja, uma alma patriótica virtuosa, amor ardente à pátria, uma nova inclinação às paixões dos poloneses (Rousseau, 1982, pp.30-31). Mas como efetivar isso? "Começai por dar aos poloneses uma grande opinião de si mesmos e de sua pátria" (idem, ibidem). O que temos então é que deve-se reforçar o sentimento de orgulho, já apresentado como marca constitutiva da identidade, de acordo com a passagem do Segundo Discurso citada acima, dandolhe um novo objeto: o público, a nação, a pátria. ${ }^{42}$

$\mathrm{Na}$ segunda possibilidade de leitura trata-se de dar o passo para o Contrato Social. Da perspectiva de leitura que adotamos aqui, visamos a entender o Contrato Social, ou pelo menos alguns de seus elementos, a partir da direção dada pela

42 Nesta mesma linha temos: "Ora, como a tendência no sentido de se distinguir e de aparecer é própria da vida em sociedade, deve ela ser aproveitada e a distinção será a distinção como patriota" (Salinas Fortes, 1997, p.130). 
seguinte passagem do "Prefácio" do Segundo Discurso:

Do concurso e da combinação que nosso espírito seja capaz de fazer desses dois princípios (a conservação de si e a piedade natural), sem que seja necessário nela imiscuir o da sociabilidade, parecem-me decorrer todas as regras do direito natural, regras essas que a razão depois é forçada a restabelecer com outros fundamentos quando, por seus desenvolvimentos sucessivos, chega a ponto de sufocar a natureza (Rousseau, 1988, p.35).

Como já visto, a piedade natural e a conservação de si como princípios do Direito Natural caracterizavam um estágio pré e protossocial (o estado de natureza). Com o advento da sociabilidade, alteram-se esses dois princípios, bem como a sua relação de "concurso e combinação", pois os desenvolvimentos da razão chegam a "sufocar a natureza". Esta é a situação a ser enfrentada pelo Contrato Social em que a sociabilidade e uma razão altamente instrumental - resultante de um processo de individuação conduzido pelo desenvolvimento (autônomo-atomizado) da conservação de si - são dados como pontos de partida para a reflexão e a prática.

Antes porém de concluir, mais algumas frases que podem ajudar a ver como Rousseau pensa dois modelos diferentes de crítica: um hipotético e outro normativo. Como já visto anteriormente, Rousseau tem um diagnótico de seu tempo que é o de um desequílibrio, ou melhor, de um equilíbrio instável constitutivo do estado de sociedade e do estado civil. Tomando isso como ponto de partida, cabe então perguntar primeiramente quais são os parâmetros, os padrões a partir dos quais Rousseau produz um tal dignóstico. De nosso ponto de vista, dois são estes parâmetros: o equilíbrio do estado de natureza e o padrão ideal do Contrato Social. Esses dois padrões de julgamento, dois modelos de crítica, desempenham diferentes funções na filosofia política de Rousseau. Ambos os parâmetros são inalcançáveis. Entretanto, o equilíbrio próprio do estado de natureza, tal como hipoteticamente reconstruído no Discurso sobre o fundamento e da desigualdade entre os homens, é um padrão inalcançável no qual o filósofo supôs um estado prévio de equilíbrio que foi rompido e perdido de uma vez por todas. 0 padrão do estado de natureza é, por assim dizer, um padrão absoluto de julgamento (o do equilíbrio perfeito). A função desse padrão é absolutamente crítica; apesar de seu ponto de partida ser a sociedade presente, Rousseau não assume qualquer forma de compromisso, seja com sua justificação, seja com uma possível reforma. O padrão do estado de natureza bloqueia a possibilidade de uma justificação e legitimação do estado presente, na medida em que impede uma naturalização das formas de dominação vigentes, ao mesmo tempo em que mostra as origens do desequilíbrio civil e firma alguns dos elementos da natureza humana que terão de ser considerados mesmo no estado societário, onde se encontram radicalmente transformados. Enquanto o padrão do Contrato Social se põe na relatividade da natureza corrompida (ou de um equilíbrio 
instável), o modelo do Contrato Social tem a função de permitir a crítica da sociedade (“crítica" num sentido diferente do Segundo Discurso), como também a de orientação da ação humana em sociedade. Por isso seu estatuto não pode ser dito hipotético mas sim ideal, normativo (entendido como procedural, já que tem em vista propor as condições de possibilidade e legitimação do contrato). Mas paremos por aqui, já que esse seria assunto para um novo artigo.

Antes de fecharmos este texto - pois não se trata de concluir, já que a ideia é que essa opção de leitura abra outras possibilidades - faz-se necessário que retomemos a pergunta da qual partimos: tendo mostrado como os "insights" teóricos de Rousseau podem ser pensados como convergindo para uma linha que se orienta na direção da teoria do reconhecimento, ainda nos restaria explicitar de que tipo seria ela. Para que pudessemos dar uma resposta apropriada a esta questão, teríamos que lidar com conceitos tais como negatividade e intersubjetividade, cujo peso é enorme na história da Teoria Critíca, e tal discussão nos levaria muito longe, muito além do que pretendemos tratar aqui. No entanto, acredito que as relações conceituais em Rousseau, como apresentado neste artigo se aproximam muito da discussão entre Joel Whitebook (2001) e Axel Honneth (2001) e eu gostaria de fechar este texto apresentando essas afinidades. Neste debate, Whitebook acusa Honneth de um défict de negatividade nas suas formulações, que tem por base o conceito de intersubjetividade.

Ainda que não haja dúvida de que a virada intersubjetiva tenha sido um evento decisivo no desenvolvimento da filosofia política e social, algo importante é deixado de lado quando o modo de teorizar que a precedeu é rejeitado sem mais. Hoje em dia, quando o intersubjetivismo periga tornar-se o mais significativo viés teórico de nossos tempos - ao qual se adere com confiança e tão acriticamente como se dava com o hobbesianismo que o precedeu - há razão para nos preocuparmos (Whitebook, 2001, p.755).

Honneth se faz uma pergunta na introdução de sua resposta à crítica de Whitebook que parece incidir exatamente sobre a indagação que dirigimos ao texto de Roussseau: “Por que uma teoria da sociedade só pode ser 'crítica' quando ela, em suas premissas teóricas sobre a socialização, parte da aceitação de que entre o self individual e a ordem há um conflito estrutural que se manisfesta sob a foram de uma ‘negatividade' do sujeito?” (Honneth, 2001, p.790)

Acredito que o pensamento de Rousseau se apresenta como um solo privilegiado para se articularem novas maneiras de pensar ou, quem sabe, de alargar as relações conceituais entre negatividade e crítica, mesmo que com isso se precise suportar o peso dos paradoxos desse homme à paradoxes, já que em Rousseau esses paradoxos não são apresentados como pontos para onde todas as soluções convergem, mas sim como um espectro que permite diferentes feixes de leitura. Ou seja, para Rousseau o 
paradoxo não constitui um problema a ser resolvido, mas se apresenta como condição de possibilidade do pensar. Uma dessas possibilidades, esperamos ter demonstrado, se coaduna com a teoria do reconhecimento, tendo em vista que para ambos os autores o papel do olhar é fundamental para se pensar a intersubjetividade. Apesar dessa intersubjetividade não poder ser pensada como a honnethiana, ela nos permite orquestrar de maneira diversa termos como negatividade, crítica, normatividade e, fundamentalmente, reconhecimento.

\section{Referências}

Cassirer, E. (1997). A Questão Jean-Jacques Rousseau. São Paulo: Editora Unesp.

Goldschmidt, V. (1974). Antropologie et Politique: Les Principes du Système De Rousseau. Paris: Vrin.

Honneth, A. (1991). Critique of Power: Reflective Stages in a Critical Social Theory. Cambridge: MIT Press.

(2001). Facetten des vorsozialen Selbst. Eine Erwiderung auf Joel Whitebook. PSYCHE. Zeitschrift für Psychoanalyse und ihre Anwendungen, 55, pp.790-802.

(2003). Luta por Reconhecimento - A Gramática Moral dos Conflitos Sociais. São Paulo: Editora 34.

Rousseau, J-J. (1964). CEuvres Complètes, tome III - Du Contrat Social, Écrits Politiques. Collection Bibliothèque de la Pléiade. Paris : Gallimard.

(1969). Lettre à Christophe de Beaumont. In : Oeuvres complètes, tome IV - Éducation - Moral - Botanique. Collection Bibliothèque de la Pléiade. Paris : Gallimard.

- (1982). Considerações Sobre o Governo da Polônia e sua Reforma Projetada. São Paulo: Editora Brasiliense.

- (1995). Discurso sobre a economia política. Tradução de Maria Constança Peres Pissarra. Petrópolis, Rio de Janeiro: Editora Vozes.

(1998). "Discurso sobre a origem e os fundamentos da desigualdade entre os homens". In: Os Pensadores. Tradução de Lourdes Santos Machado. São Paulo: Editora Nova Cultural.

Salinas Fortes, L. R. (1997). O Paradoxo do Espetáculo: Política e Poética em Rousseau. São Paulo: Discurso Editorial. - (1976). Rousseau: da Teoria à Prática. São Paulo: Ática.

Voltaire. (1971). «Lettre de Voltaire a Jean-Jacques Rousseau de 30/08/1755». In: Rousseau, J.J. Oeuvres Complètes, tome II. Paris: Éditions du Seuil

Whitebook, J. (2001). Wechselseitige Anerkennung und die Arbeit des Negativen. PSYCHE. Zeitschrift für Psychoanalyse und ihre Anwendungen, 55, pp.755-789.

Recebido em: 21.10.2016

Aceito em: 20.01.2017 